\title{
E-Banking Effects on Customer Satisfaction: The Survey on Clients in Jordan Banking Sector
}

\author{
Thabit Altobishi ${ }^{1}$, Gizem Erboz ${ }^{1} \&$ Szilárd Podruzsik ${ }^{2}$ \\ ${ }^{1}$ School of Management and Business Administration, Szent Istvan University, Gödöllö, Hungary \\ ${ }^{2}$ School of Business and Management, Corvinus University of Budapest, Budapest, Hungary \\ Correspondence: Gizem Erboz, School of Management and Business Administration, Szent Istvan University, \\ Gödöllö, Páter Károly St. 1, 2100, Hungary.
}

Received: March 14, 2018 Accepted: May 19, 2018 Online Published: May 24, 2018

doi:10.5539/ijms.v10n2p151 URL: https://doi.org/10.5539/ijms.v10n2p151

\begin{abstract}
In general, the managers in financial organizations and institutions are willing to maintain customer satisfaction, in order to minimize their cost and strengthen their competitive advantage.In Jordan, most of the commercial banks offer their banking services electronically. Therefore, this research aims to investigate the effects of electronic banking services on customer satisfaction in the lights of survey questions asked to 175 clients in Jordan. The reviewed literature indicates that convenience, privacy, cost, ease of use, personalization and customization and security are six indicators that affect level of customer satisfaction with E-Banking. The survey questions conducted in these six indicators and statistical results shows a positive relationship between level of customer satisfaction and usage of E-Banking among customers. There is positive relationship between five indicators and level of customer satisfaction and usage of E-Banking. Only Privacy is not discovered to have an effect on Customer Satisfaction in Jordan.
\end{abstract}

Keywords: E-banking, customer satisfaction, E-commerce, electronic banking, Jordanian banks

\section{Introduction}

Development of internet banking is a contribution to a most efficient delivery of bank services and to a higher, faster and cheaper merchandise. Customers can browse essential bank merchandise and services in 24 hours using their personal computers. Now, most of customers could perform through the benefits of Internet Banking due to achieving their banking transactions and activities anytme from any location (Tarhini et al., 2015). One of the main internet banking services are informational. Informational internet banking is a basic form of internet banking that offers comprehensive bank merchandise and services (Zolait \& Sulaiman, 2017; Poon, 2007). It provides not only historical information of the bank but also additional information such as its structure, its membership in networks with bank clusters, retail and specialized banking facilities or companies. This type of internet banking does not involve any execution of transactions (Fatimah \& Suyanto, 2016).

Financial organizations use data and IT for data analysis to support the decision making process. Besides, they differentiate their offers from competitors and tend to become pioneer rather than their competitors while satisfying the needs of customers. These establishments use the foremost innovative technologies to achieve customer satisfaction and supply them the chance of performing arts on interactive retail banking (Calisir \& Gumussoy, 2008).

According to Abid and Noreen (2006) electronic banking outlined as any use of knowledge and communication technology and electronic means that by a bank to conduct transactions and interact with stakeholders. E-banking could be a generic term for delivery of banking services and product through electronic channels, like computers, cellular phones, and web. The thought and level of e-banking are still booming. It facilitates method of accounting and effective payment thereby enhancing the speed of delivery of banking services significantly (Uppal \& Jatana, 2007).

E-Banking activities are taken strong emphasis in the last years. Akhisar et al. (2015) advocates that less number of customers using e-banking services could affect performances of the banks negatively. Yang et al. (2018) mentions that banks should establish customer oriented business strategy in order to gain more loyal customers for their banking services. Therefore, the main initiative of this research is to explore the linkage between 
E-Banking usage and level of customer satisfaction. Besides, the research clarifies the dimensions of E-Banking over customer satisfaction. The importance of this research is that it would give some insights on evolving of E-Banking activities without ignoring their clients. Also, the results of this empirical research would help the researchers investigate E-Banking structures in the future.

\section{Literature Review}

\subsection{E-Banking Revolution}

The banking industry has been taken the leading position in e-business world for years. E-Banking Revolution has fundamentally changed the business of banking by scaling borders and bringing new opportunities. In simple words, E-Banking implies provision of banking products and services through electronic distribution channels. Electronic banking has been considered sometimes in the form of automatic teller machines (ATMs) and telephone transactions. Recently, it has been transformed by internet. The new delivery channel facilitates banking transactions for both banks and customers. The internet offers faster access to the bank services for customers that is more suitable and available around the clock irrespective of the customer's location (Chavan, 2013). The internet banking phenomenon has transformed the banking mode and method and it has brought new strategic directions for investment in banking information and communication technologies (Sabi, 2014).

The network which connects the various locations and gives connectivity to the central office within the organization is called intranet. Those intranet networks are limited to the organizations that use it (Vyas, 2012). Internet banking is now used as the term for new age banking system Internet banking is defined as the use of Internet to deliver banking activities such as funds transfer, viewing current account's data, paying bills and savings account balance, purchasing financial instruments and paying mortgages and certificates of deposits (Singhal \& Padhmanbhan, 2008; Opara et al., 2016).

E-payment is described as that whereby banking businesses are transacted through automated processes and electronic devices such as personal computers, telephones, and fax machines, Internet card payments and other electronic channels (Chaudhry et al., 2016; Opara et al., 2016).

Only few innovations have revolutionized the banking sector as fast as the E-banking has done. Now, the banks are reorienting their business strategies towards new opportunities offered by E-Banking. E-Banking enables banks to scale borders, thus bring new possibilities and change strategic behavior. E-Banking has moved real banking behavior closer to neoclassical economic theories of market functioning. View of the absolute transparency of the market, clients (both business as well as retail) can compare the services of various banks more easily. From point of view of the banks, the web has considerably reduced the physical prices of banking operations (Chavan, 2013).

\subsection{Customer Satisfaction}

In the advent of 21st century, E-Banking revolution has an impact nearly each facet of human life. The new data technologies have some alters the whole image of service sector (Gautam, 2013). Despite banks attempt to mitigate shopper problems through giving on-line accounts that generally attract diluted fees and better interest, managing the continuing tension between potency and human interaction represents a challenge to banking establishments (Herington \& Weaven, 2009).

The distinctive nature of the services, with the emergency of technology, had semiconductor to contentions with internet banking. Despite the efficiencies created by e-banking, continuing dependency on human reactions, many business area units are still keeping duplicative ancient records and activity ancient banking tasks that cause but full implementation of the technology (Wong et al., 2008).

Banks on the planet are effectively deploying data technology as associate degree innovative resource to realize speed, efficiency, value reduction, client service and competitive advantage. Technology enabled product and delivery channels provide banking activities to customers in anyplace and anytime (Joshua et al., 2011). The previous research on E-Banking indicates that the perceived quality of E-Banking services has a strong influence on customer satisfaction and use of E-Banking (Ayo et al., 2016; Amin, 2016; George \& Kumar, 2014).

\section{Hypothesis 1: As the lights of literature, we generate the main hypothesis of this study is that E- banking positively affects customer satisfaction.}

\subsection{Convenience of E-Banking}

Internet banking gains an extraordinary acceptance in several countries because of its advantages for both banks and customers. Adapa \& Rindfleish (2013) indicate that developed countries embrace technological innovations at a quicker pace; which internet banking is strongly adopted by many shoppers. 
The structural relationships among electronic service quality, total satisfaction and total service quality are examined by Kayabasi et al. (2013). A high level correlation has been found between perception of total service quality and perception of total satisfaction. The benefit of use, variables responsiveness, security and products portfolio, which are the scales of e-service quality, have an effect on total satisfaction perception and total service quality perception in parallel with the literature. Security and responsiveness have shown the best result on e-service quality perception.

\section{Hypothesis 2: Convenience of E-Banking has positive impact on customer satisfaction.}

\subsection{Privacy Issues}

"Information Privacy refers to the desire of individuals to control or have some influence over data about themselves" (Bélanger \& Crossler, 2011). The other studies also deal with the connection of Privacy and adoption of E-Banking (Chiu et al., 2016; Lee, 2009; Masoud \& AbuTaqa, 2017). There are many concerns about privacy of personal information and context confidentiality might hinder customers from exploitation web banking, a reality that emphasizes the importance of problems associated with privacy and security. The necessary gaps must be filled regarding privacy concerns of clients on web banking.

\section{Hypothesis 3: Reducing Privacy disputes on E-Banking positively affect on customer satisfaction.}

\subsection{Cost of E-Banking}

Customers are willing to pay low service charge for banking services. Even satiny low fee per group action will become an enormous revenue generator, banks don't have to be compelled to still expose e-services for gratis, but if they hope to charge for them, they're doing ought to higher communicate the convenience and worth of these services (Valentine, 2014).

Customers demand retail bank transactions whose volume depends on the complete price of conducting a transaction. Full prices are obligatory on customers in three ways: worth, technology preferences, and distance traveled to conduct a group action. In applying, retail banks charge costs in several ways; most known is indirect costs. Samples of the ways in which retail banks charge costs embrace fees for a selected service, minimum account balances, periodic fees, and deals for packages of services. Customers are sensitive to the gap as that they have to trip conduct a group action. Since banks place multiple locations throughout a vicinity, and customers travel at random among the region, it's cheap to assume that customers don't live their distance to one retail spiral outlet in evaluating their banking relationship (Reynold et al., 2011).

\section{Hypothesis 4: Cost advantage of E-Banking has positive impact on customer satisfaction.}

\subsection{Ease of Use}

Rapidly growing and dynamic revolutionized technologies have overwhelmed the world of financial institutions. Those form of technological advancement has enhanced delivery of banks' services, it has an enormous effect on development of more flexible payments methods and more user-friendly banking services (Dixit \& Datta, 2010). Technologies enable both customers and employees to be more effective in getting and providing services. During self-service technologies customers can serve themselves more effectively (Wilson et al., 2016). For example, via online banking customers can access their accounts, apply for loan, check balances, shift money among accounts, and take care of their banking activities without the assistance of the employees of banks (Ismail \& Osman, 2012).

\section{Hypothesis 5: Ease of Use of E-Banking Services has a positive effect on customer satisfaction.}

\subsection{Personalization and Customization}

Sundar and Marathe (2010) have defined the potential mediators of customization in terms of customer perspective. Providing high customization drives the tangible benefits on customers and strong control for them via using their system. In E-Banking, the service gives the opportunities on electronic bill paying, mobile banking, provide paying the bills from the computer or smart phone, eliminating the disputes to write checks and buy stamps. Instead, once you enter your payment or account details to create a standing list, simply, the web page forwards you to your banking profile and the clients can type the amount of payment and click to send a payment each month (Kolodinsky et al., 2004; Wang et al., 2017; Moro et al., 2015). Another easy way of E-Banking is that customers could put recurring level payments for such expenses as insurance, your mortgage, or a car loan on autopilot, and they'll be deducted each month on a certain date you set.. Customers also tend to bank bill pay services to the automatic electronic pay option offered by many utilities, insurers, lenders, and other companies, because it gives the customer more control over when and if a particular bill should be paid (Herzberg, 2003). 


\section{Hypothesis 6: Personalization and Customization of E-Banking positively affect on customer satisfaction.}

\subsection{Security}

Three reasons that consumers do not trust internet technology relate to security of the system, worries about the reliability of internet services, and distrust of service providers. Reputation is also considered important, as distrust of the service provider is a related factor. The risk associated with the service is also the best reason for avoiding of internet banking usage (Yousafzai, Pallister, \& Foxall, 2003). Risk is related to reliability and system failure. Risk usually arises from uncertainty when consumers cannot foresee the consequences of their use of a certain product or service. Demographics may also be relevant in understanding the use patterns of internet banking (Adapa \& Rindfleish, 2013). Ilett (2005) confirms the difficulties of attracting mature-age consumers on internet banking use. Grabner-Krauter and Faullant (2008) advocate that gender may also be a relevant factor influencing consumer resistance to use internet banking, as women are regarded privacy protection and ethical standards more seriously than men.

\section{Hypothesis 7: Secure services of E-Banking positively affect on customer satisfaction.}

\section{Method}

\subsection{Questionnaire and Sample Characteristics}

Our methodological approach is to use a questionnaire in order to measure the effects of Electronic Banking efficiency over customer satisfaction in Jordan, and analyze the dimensions of E-Banking services that would affect customer satisfaction. As described in literatures, we identify the six dimensions of E-banking services on client usage; those dimensions are Convenience, Privacy, Cost, Ease of Use, Privatization and Customization and Security. The survey questions are prepared by taking into consideration of these six indicators. Before completing the possible questions that would be asked to clients, we interview about the relevance of six indicators, and the possible benefits and challenges of E-Banking over customer satisfaction with the executives and managers of some banks in Jordan and also the academicians working in some universities in Jordan. Final questions are completed in two parts; which consist of the general information about the clients and the questions about the six indicators of E-Banking services (See Appendix A). Each dimensions of E-Banking cover three questions that represent the satisfaction result of the clients. Five Likert Scale is used in measuring the satisfaction level of the clients; where 1 represents 'Strongly Disagree' while 5 represents 'Strongly Agree'. The questionnaires are sent to total 243 people in Jordan and total response is taken with 175 people. The clients were clearly selected after the interviews with the banks and many of the clients are listed in actual clients of the banks of Jordan. We also make interviews with the clients on site of the banks and E-mail is sent to some of the customers in order to reach high number of clients. Table 1 shows the characteristics of 175 observations of the clients in terms of their gender, age, educational level and job nature. The study is completed within five months in 2017.

\subsection{Multiple Regression Analysis}

In the second part of the methodology of this study, the results are tested by multiple regression analysis by selecting client satisfaction as dependent variable and the indicators of E-Banking services as independent variables. The model describes the relationship on Convenience, Privacy, Cost, Ease of Use, Personalization and Customization and Security of E-Banking services over Client Satisfaction (Figure 1). In the first phase, we identify the descriptive statistics (mean and standard deviations) of each dimension. Later, we examine the every indicators in correlation analysis whether they are correlated with each other or not. Finally, multiple regression analysis is conducted between the variables and customer satisfaction, and the relationship is tested in terms of their significance level. The equation of the mathematical model where value of $\beta$ is the regression coefficient and $\alpha$ is the value of intercept is the following;

Customer Satisfaction $=\alpha+\beta_{1} *($ Convenience $)+\beta_{2} *($ Privacy $)+\beta_{3} *($ Cost $)+\beta_{4} *($ Ease of Use $)+\beta_{5}$ (Personalization and Customization) $+\beta_{6} *$ (Security) 
Table 1. Sample characteristics of 175 observations

\begin{tabular}{llll}
\hline Variable & Categories & Frequency & Percentage \\
\hline \multirow{3}{*}{ Gender } & Male & 128 & 73.1 \\
& Female & 47 & 26.9 \\
& Total & $\mathbf{1 7 5}$ & $\mathbf{1 0 0 . 0}$ \\
\hline \multirow{4}{*}{ Age } & $20-25$ years & 24 & 13.7 \\
& $26-30$ years & 42 & 24.0 \\
& $31-35$ years & 35 & 20.0 \\
& 36-40 years & 27 & 15.4 \\
& more than 41 years & 47 & 26.9 \\
Educational Level & Total & $\mathbf{1 7 5}$ & $\mathbf{1 0 0 . 0}$ \\
& Diploma & 54 & 30.9 \\
& Bachelor & 65 & 37.1 \\
& Master & 38 & 21.7 \\
& PhD & 18 & 10.3 \\
& Total & $\mathbf{1 7 5}$ & $\mathbf{1 0 0 . 0}$ \\
\hline \multirow{3}{*}{ Job Nature } & Investor & 34 & 19.4 \\
& Trader & 72 & 41.1 \\
& Educational field & 41 & 23.4 \\
& public employee & 28 & 16.0 \\
& Total & $\mathbf{1 7 5}$ & $\mathbf{1 0 0 . 0}$ \\
\hline
\end{tabular}

Source: Authors' own findings.

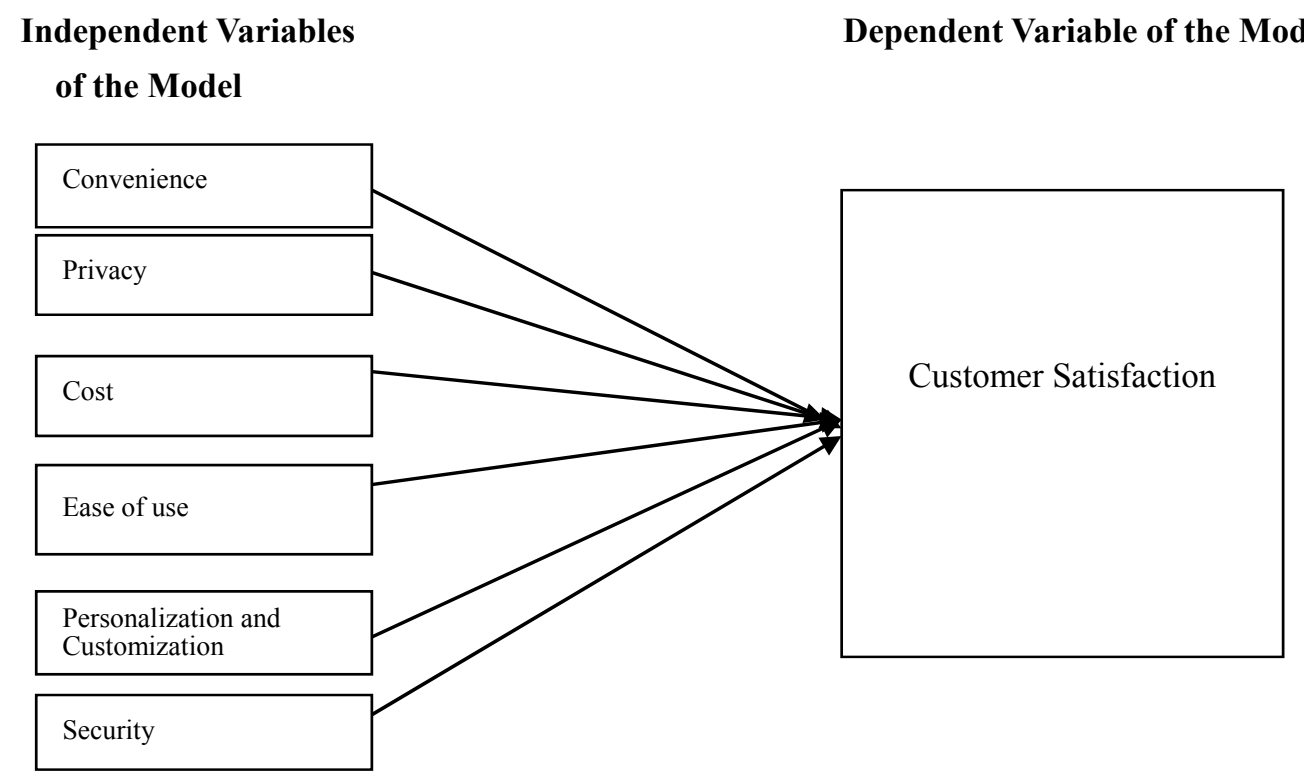

Figure 1. Model of the research

Source: Authors' own elaboration.

\section{Results and Discussions}

This section is devoted to explain the statistical results of 175 observations. In the first phase, the six dimensions are analyzed in terms of mean, standard deviation and rank (Table 2). The highest mean reached (3.92) out of (5) for rank (1) "Personalization and Customization" by high agreement degree, then for rank (2) "Privacy" and rank (3) "Security", by high agreement degree (means 3.88). And the lowest mean was (3.63) for rank (6) "Convenience" by medium agreement degree. The total means for "E- Banking" reached (3.87) by high agreement degree. 
Table 2. Means and standard deviations for each indicator of "E-Banking" and total means of them $(n=175)$

\begin{tabular}{llllll}
\hline No & Items & Mean & $\begin{array}{l}\text { Standard } \\
\text { Deviation }\end{array}$ & Rank & $\begin{array}{l}\text { Agreement } \\
\text { Degree }\end{array}$ \\
\hline 1 & Convenience & 3.63 & 0.87 & 6 & Medium \\
2 & Privacy & 3.88 & 0.81 & 2 & High \\
3 & Cost & 3.71 & 0.74 & 5 & High \\
4 & Ease of use & 3.83 & 0.91 & 4 & High \\
5 & Personalization and & 3.92 & 0.72 & 1 & High \\
6 & Customization & 3.88 & 0.98 & 2 & High \\
Total & Security & $\mathbf{3 . 8 7}$ & $\mathbf{0 . 5 2}$ & - & High \\
\hline
\end{tabular}

Source: Authors' own calculations.

In the second phase, the correlation test is conducted by six variables, whether they are correlated with each other. Regarding the results of the correlation test, only Privacy indicates correlation with the other variables; therefore, we ignore 'Privacy' indicator in multiple regression test. The last model is conducted by five variables; Convenience, Cost, Ease of Use, Personalization and Customization and Security; where the mathematical equation represents as;

Customer Satisfaction $=\alpha+\beta_{1} *($ Convenience $)+\beta_{2} *($ Cost $)+\beta_{3} *($ Ease of Use $)+\beta_{4} *($ Personalization and Customization) $+\beta_{5} *$ (Security)

Table 3 indicates the results of Multiple Regression Analysis conducted with five variables.

Table 3. The results of multiple regression analysis

\begin{tabular}{|c|c|c|c|c|c|c|c|}
\hline $\begin{array}{l}\text { Independent } \\
\text { variable }\end{array}$ & "t" value & “t” sig & Beta & $\mathbf{R}$ & $\mathbf{R}^{2}$ & “f” value & "f" sig \\
\hline Convenience & 8.593 & 0.000 & 0.309 & \multirow{5}{*}{0.907} & \multirow{5}{*}{0.822} & \multirow{5}{*}{129.412} & \multirow{5}{*}{0.00} \\
\hline Cost & 5.458 & 0.000 & 0.212 & & & & \\
\hline ease of use & 9.588 & 0.000 & 0.357 & & & & \\
\hline $\begin{array}{l}\text { personalization } \\
\text { and customization }\end{array}$ & 4.423 & 0.000 & 0.177 & & & & \\
\hline Security & 3.271 & 0.001 & 0.231 & & & & \\
\hline
\end{tabular}

* Dependent variable: Customer Satisfaction

Source: Authors' own calculation

Regarding the multiple regression results, the main and sub-hypotheses are tested as follows;

- There is a statistically positive relationship at significant level $(\alpha \leq 0.05)$ on E- banking over Customer Satisfaction in Jordanian banks, where "f" value reached (129.412) by statistically significant $(0.00)$, (R) value reached $(0.907)$ and $\left(R^{2}\right)$ value reached $(0.822)$, so the main hypothesis were accepted.

- There is a statistically positive effect at significant level $(\alpha \leq 0.05)$ of 'Convenience of E- banking' on the Customer Satisfaction in Jordanian banks, where "t" value reached (8.593) by statistically significant $(0.00)$, so the second hypothesis were accepted.

- There is no statistical relationship is found between 'Privacy' and 'Customer Satisfaction' since this indicator is removed from the model; therefore, the third hypothesis was rejected.

- There is positive relationship at significant level $(\alpha \leq 0.05)$ of 'E- banking Cost' on the Customer Satisfaction in Jordanian banks, where " $t$ " value reached (5.458) by statistically significant $(0.00)$, so the fourth hypothesis were accepted.

- There is a statistically positive effect at significant level $(\alpha \leq 0.05)$ of 'Ease of Use of E- banking' on the Customer Satisfaction in Jordanian banks, where " $\mathrm{t}$ " value reached (9.588) by statistically significant $(0.00)$, so the fifth hypothesis were accepted.

- There is a statistically positive effect at significant level $(\alpha \leq 0.05)$ of 'Personalization and Customization of E-Banking' on the Customer Satisfaction in Jordanian banks, where " $\mathrm{t}$ " value reached (4.423) by statistically significant $(0.00)$, so the sixth hypothesis were accepted. 
- $\quad$ There is a statistically positive relationship at significant level $(\alpha \leq 0.05)$ of 'Security of E- banking' on the Customer Satisfaction in Jordanian banks, where " $\mathrm{f}$ " value reached (3.271) by statistically significant (0.001), so the seventh hypothesis were accepted.

\section{Conclusions}

Banks tend to gain knowledge and understand of customers' expectations and needs accurately. Therefore, customer satisfaction and service delivery of the banks are not being seperated, further analysis should be conducted between them. Our empirical study consists of whether E-Banking services have an impact on customer satisfaction. Regarding the final results, E-Banking services and Customer Satisfaction show a positive relationship statistically. The six variables are identified as the dimensions of E-Banking on customer satisfaction; those variables are convenience, cost, privacy, ease of use, personalization and customization and security. The effects of these variables (convenience, cost, ease of use, personalization and customization and security) have been found as positive on influencing customer satisfaction in banking sector. Privacy indicator is eliminated from the model since this variable is correlated with the other variables.

The study represents the client satisfaction in Jordanian banks; however, the future work would concentrate on more observations on the other countries and comparisons of geographical differences on E-Banking. Besides, more variables could be added into the study in order to achieve more consistency on statistical results.

\section{References}

Abid, H., \& Noreen, U. (2006). Ready to e-bank: An exploratory research on adoption of e-banking and e-readiness among customers and commercial banks in Pakistan. Spider, 31(2), 131.

Adapa, S., \& Rindfleish, J. (2013). Internet Banking Non-Users: Thematic Matrix Display Analysis. International Journal of Business and Information, 8(2).

Akhisar, I., Tunay, K. B., \& Tunay, N. (2015). The effects of innovations on bank performance: The case of electronic banking services. Procedia-Social and Behavioral Sciences, 195, 369-375. https://doi.org/10.1016/j.sbspro.2015.06.336

Amin, M. (2016). Internet banking service quality and its implication on e-customer satisfaction and e-customer loyalty. International Journal of Bank $280-306$. https://doi.org/10.1108/IJBM-10-2014-0139

Ayo, C. K., Oni, A. A., Adewoye, O. J., \& Eweoya, I. O. (2016). E-banking users' behaviour: E-service quality, attitude, and customer satisfaction. International Journal of Bank Marketing, 34(3), $347-367$. https://doi.org/10.1108/IJBM-12-2014-0175

Bauer, H. H., Hammerschmidt, M., \& Falk, T. (2005). Measuring the quality of e-banking portals. International Journal of Bank Marketing, 23(2), 153-175. https://doi.org/10.1108/02652320510584395

Bélanger, F., \& Robert, C. (2011). Privacy in the Digital Age: A Review of Information Privacy Research in Information Systems. MIS Quarterly, 35(4), 1017-1042. https://doi.org/10.2307/41409971

Calisir F., \& Gumussoy C. (2008). Internet banking versus other banking channels: Young customers' view. International Journal of Information $215-221$. https://doi.org/10.1016/j.ijinfomgt.2008.02.009

Chaudhry, S. A., Farash, M. S., Naqvi, H., \& Sher, M. (2016). A secure and efficient authenticated encryption for electronic payment systems using elliptic curve cryptography. Electronic Commerce Research, 16(1), 113-139. https://doi.org/10.1007/s10660-015-9192-5

Chavan, J. (2013). Internet Banking- Benefits and Challenges in an Emerging Economy. International Journal of Research in Business Management (IJRBM), 1(1), 19-26.

Chiu, C. L., Chiu, J. L., \& Mansumitrchai, S. (2016). Privacy, security, infrastructure and cost issues in internet banking in the Philippines: initial trust formation. International Journal of Financial Services Management, 8(3), 240-271. https://doi.org/10.1504/IJFSM.2016.080119

Dixit, R., \& Datta, E. (2010). Acceptance of E-banking among adult customers: An empirical investigation in India. Journal of Internet Banking and Commerce, 15.

Fatimah, E. O., \& Suyanto, A. M. A. (2016). Analysis Factors of Using Internet Banking in Indonesia. Management and Organizational Studies, 3(2), 10. https://doi.org/10.5430/mos.v3n2p10

Gautam, V. (2013). Measuring the Impact of New Technologies through Electronic Banking on Profitability of 
Banks: Evidence form Indian Banking Industry. Research Scholar, ICFAI University Dehradun, Uttrakhand (India).

George, A., \& Kumar, G. G. (2014). Impact of service quality dimensions in internet banking on customer satisfaction. Decision, 41(1), 73-85. https://doi.org/10.1007/s40622-014-0028-2

Grabner-Krauter, S., \& Faullant, R. (2008). Consumer acceptance of internet banking: The influence of internet trust. International Journal of Bank Marketing, 26(7), 483-504. https://doi.org/10.1108/02652320810913855

Herington, C., \& Weaven, S. (2009). E-Retailing by Banks: E-Service Quality and Its Importance to Customer

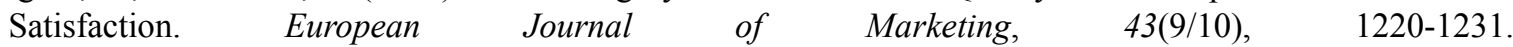
https://doi.org/10.1108/03090560910976456

Herzberg, A. (2003). Payments and banking with mobile personal devices. Communications of the ACM, 46(5), 53-58. https://doi.org/10.1145/769800.769801

Ilett, D. (2005). Online Bankers to Double by 2010. Retrived from www.silicon.com/financialservices

Ismail, M., \& Osman, M. (2012). Factors Influencing the Adoption of E-banking in Sudan: Perceptions of Retail Banking Clients. Journal of Internet Banking and Commerce, 17(3).

Joshua, A. J., \& Koshy, M. P. (2011). Usage Patterns of Electronic Banking Services by Urban Educated Customers: Glimpses from India. Journal of Internet Banking and Commerce, 16(1).

Kayabasi, A., Çelik, B., \& Büyükarslan, A. (2013). The analysis of the relationship among perceived electronic service quality, total service quality and total satisfaction in Banking sector. Journal of Human Sciences, 10(2), 304-325.

Kolodinsky, J. M., Hogarth, J. M., \& Hilgert, M. A. (2004). The adoption of electronic banking technologies by US consumers. International Journal of Bank Marketing, 22(4), 238-259. https://doi.org/10.1108/02652320410542536

Lee, M. C. (2009). Factors influencing the adoption of internet banking: An integration of TAM and TPB with perceived risk and perceived benefit. Electronic Commerce Research and Applications, 8(3), 130-141. https://doi.org/10.1016/j.elerap.2008.11.006

Masoud, E., \& AbuTaqa, H. (2017). Factors Affecting Customers' Adoption of E-Banking Services in Jordan. Information Resources Management Journal (IRMJ), 30(2), 44-60. https://doi.org/10.4018/IRMJ.2017040103

Moro, S., Cortez, P., \& Rita, P. (2015). Business intelligence in banking: A literature analysis from 2002 to 2013 using text mining and latent Dirichlet allocation. Expert Systems with Applications, 42(3), 1314-1324. https://doi.org/10.1016/j.eswa.2014.09.024

Opara, B. C., Ozuru, H. N., \& Akahome, J. E. (2016). CUSTOMER ATTITUDE AND USAGE OF INTERNET BANKING SERVICES IN RIVERS STATE, NIGERIA. Sustainable Human Development Review, 6(1-4).

Poon, W. C. (2007). Users' adoption of e-banking services: the Malaysian perspective. Journal of Business \& Industrial Marketing, 23(1), 59-69. https://doi.org/10.1108/08858620810841498

Reynold, E., \& Philip J. (2011). Retail Bank Services Strategy: A Model of Traditional, Electronic, and Mixed Distribution Choices. Journal of Management Information Systems, 18(2), 133-156.

Sabi, H. M. (2014). Research Trends in the Diffusion of Internet Banking in Developing Countries. Journal of Internet Banking and Commerce, 19(2).

Singhal, D., \& Padhmanabhan, V. (2008). A Study on Customer Perception Towards Internet Banking: Identifying Major Contributing Factors. The Journal of Nepalese Business Studies, 1, 101-111.

Sundar, S. S., \& Marathe, S. S. (2010). Personalization versus customization: The importance of agency, privacy, and power usage. Human Communication Research, 36(3), 298-322. https://doi.org/10.1111/j.1468-2958.2010.01377.x

Tarhini, A., El-Masri, M., Ali, M., \& Serrano, A. (2016). Extending the UTAUT model to understand the customers' acceptance and use of internet banking in Lebanon: A structural equation modeling approach. Information Technology \& People, 29(4), 830-849. https://doi.org/10.1108/ITP-02-2014-0034

Uppal, R. K., \& Jatana, R. (2007). E-banking in India: challenges and opportunities. SBN: 8177081373. p. 266. 
Valentine, L. (2014). Long-simmering question of whether or not to charge for e-payments heats up as payment options increase. ABA Banking Journal, April.

Vyas, S. D. (2012). Impact of e-banking on traditional banking services. arXiv preprint arXiv:1209.2368.

Wang, M., Cho, S., \& Denton, T. (2017). The impact of personalization and compatibility with past experience on e-banking usage. International Journal of Bank Marketing, 35(1), 45-55. https://doi.org/10.1108/IJBM-04-2015-0046

Wilson, A., Zeithaml, V., Bitner, M. J., \& Gremler, D. (2016). Services marketing: Integrating customer focus across the firm. McGraw Hill.

Wong, D. H., Rexha, N., \& Phau, I. (2008). Re-examining traditional service quality in an e-banking era. International Journal of Bank Marketing, 26(7), 526-545. https://doi.org/10.1108/02652320810913873

Yang, S., Li, Z., Ma, Y., \& Chen, X. (2018). Does Electronic Banking Really Improve Bank Performance? Evidence in China. International Journal of Economics and Finance, 10(2), 82. https://doi.org/10.5539/ijef.v10n2p82

Yousafzai, S. Y., Pallister, J. G., \& Foxall, G. R. (2003). A proposed model of e-trust for electronic banking. Technovation, 23(11), 847-860. https://doi.org/10.1016/S0166-4972(03)00130-5

Zolait, A. H. S., \& Sulaiman, A. (2017). The influence of communication channels on internet banking adoption. Asian Journal of Business and Accounting, 2(1\&2), 115-134.

\section{Appendix A}

\section{The Questions Asked to the Clients}

\section{A1. Demographic Information}

(1) Gender

$\square$ Male $\square \quad$ Female

(2) Age

20-25 years

$26-30$ years

$\quad 31-35$ years

$\quad 36-40$ years

$\square \quad$ More than4lyears

(3) Educational Level

$\square \quad$ Diploma

(4) Job Nature

$\square \quad$ Investor $\square \quad$ Trader $\square \quad$ Educational field $\square \quad$ public employee

(5) How many banks that you deal with?

$\square \quad$ One Only $\quad \square \quad$ More than One

(6) Which E- Banking services you mostly use?

ATM $\square \quad$ Transactions by internet $\square \quad$ Transferring funds

Secondly: usage of E-Banking services

1- Do you permanently use (ATM)? $\square$ Yes $\square$ No

2- Do you use Credit card like Visa Card? $\square$ Yes $\square$ No

3- Do you use house-bank through internet? $\square$ Yes $\square$ No

4- Do you use mobile to get banking service? $\quad$ Yes $\quad \square$ No

5- Do you get E-mail notification from bank via mobile or computer? $\square$ Yes $\square$ No

\section{A2. E-banking Services}

Please write $(\backslash)$ under the suitable alternative of the following statement. 


\section{Convenience measurement}

\begin{tabular}{|c|c|c|c|c|c|c|}
\hline Number & Item & $\begin{array}{l}\text { Strongly } \\
\text { agree }\end{array}$ & Agree & Neutral & Disagree & $\begin{array}{l}\text { Strongly } \\
\text { disagree }\end{array}$ \\
\hline 1 & $\begin{array}{l}\text { E-banking services are fit with } \\
\text { my needs and wills }\end{array}$ & & & & & \\
\hline 2 & $\begin{array}{l}\text { E-banking services afford great } \\
\text { facilities }\end{array}$ & & & & & \\
\hline 3 & $\begin{array}{l}\text { You can carry out E-banking } \\
\text { services anywhere }\end{array}$ & & & & & \\
\hline
\end{tabular}

\section{Privacy measurement}

\begin{tabular}{|c|c|c|c|c|c|c|}
\hline Number & Item & $\begin{array}{l}\text { Strongly } \\
\text { agree }\end{array}$ & Agree & Neutral & Disagree & $\begin{array}{l}\text { Strongly } \\
\text { disagree }\end{array}$ \\
\hline 4 & $\begin{array}{l}\text { E-banking servicesare } \\
\text { confidential }\end{array}$ & & & & & \\
\hline 5 & $\begin{array}{l}\text { Using E-banking services } \\
\text { provides privacy }\end{array}$ & & & & & \\
\hline 6 & $\begin{array}{l}\text { Client's privacy is one of the } \\
\text { main features of E-banking } \\
\text { services }\end{array}$ & & & & & \\
\hline
\end{tabular}

\section{Cost measurement}

\begin{tabular}{|c|c|c|c|c|c|c|}
\hline Number & Item & $\begin{array}{l}\text { Strongly } \\
\text { agree }\end{array}$ & Agree & Neutral & Disagree & $\begin{array}{l}\text { Strongly } \\
\text { disagree }\end{array}$ \\
\hline 7 & $\begin{array}{l}\text { E-banking services are very } \\
\text { cheap }\end{array}$ & & & & & \\
\hline 8 & $\begin{array}{l}\text { E-banking services contribute in } \\
\text { decreasing the price of service }\end{array}$ & & & & & \\
\hline 9 & $\begin{array}{l}\text { E-banking services save money } \\
\text { spent in going to-and-from the } \\
\text { bank to get the service }\end{array}$ & & & & & \\
\hline
\end{tabular}

\section{Ease of use measurement}

\begin{tabular}{lllll}
\hline Number & Item & $\begin{array}{l}\text { Strongly } \\
\text { agree }\end{array}$ & $\begin{array}{c}\text { Agree } \\
\text { neutral }\end{array}$ & $\begin{array}{c}\text { Disagree } \\
\text { disagree }\end{array}$ \\
\hline 10 & E-banking services are very simple & & \\
11 & E-banking service performs service & & \\
& immediately & & \\
12 & It is easy for you to become skillful & & \\
& at using Electronic Banking. & & \\
\hline
\end{tabular}

\section{Personalization and customization measurement}

\begin{tabular}{|c|c|c|c|c|c|c|}
\hline Number & Item & $\begin{array}{c}\text { Strongly } \\
\text { agree }\end{array}$ & Agree & Neutral & Disagree & $\begin{array}{l}\text { Strongly } \\
\text { disagree }\end{array}$ \\
\hline 13 & $\begin{array}{l}\text { There is no difficulty in dealing } \\
\text { with your personal page setup on } \\
\text { the internet }\end{array}$ & & & & & \\
\hline 14 & $\begin{array}{l}\text { Electronic-banks are distinguished } \\
\text { with attractive design and } \\
\text { consistent colors }\end{array}$ & & & & & \\
\hline 15 & $\begin{array}{l}\text { You can change color, language } \\
\text { and other webpage settings }\end{array}$ & & & & & \\
\hline
\end{tabular}




\section{Security measurement}

\begin{tabular}{|c|c|c|c|c|c|c|}
\hline Number & Item & $\begin{array}{l}\text { Strongly } \\
\text { agree }\end{array}$ & Agree & Neutral & Disagree & $\begin{array}{l}\text { Strongly } \\
\text { disagree }\end{array}$ \\
\hline 16 & Using E-banking services is safe & & & & & \\
\hline 17 & $\begin{array}{l}\text { Using ATM and Credit Cards are } \\
\text { not dangerous }\end{array}$ & & & & & \\
\hline 18 & $\begin{array}{l}\text { E-banking services supply a } \\
\text { sufficient control through } \\
\text { controlling procedures applied on } \\
\text { input, output and processes for the } \\
\text { safety of the client. }\end{array}$ & & & & & \\
\hline
\end{tabular}

\section{Satisfaction measurement}

\begin{tabular}{lllll}
\hline Number & Item & $\begin{array}{l}\text { Strongly } \\
\text { agree }\end{array}$ & $\begin{array}{c}\text { Agree } \\
\text { Neutral }\end{array}$ & $\begin{array}{c}\text { Disagree } \\
\text { disagree }\end{array}$ \\
\hline 19 & $\begin{array}{l}\text { I am satisfied about the E-banking } \\
\text { data and services in bank website }\end{array}$ & \\
& $\begin{array}{l}\text { I will strongly recommend others to } \\
\text { use online Banking }\end{array}$ \\
& I will continue to use Electronic \\
& Banking services in the future
\end{tabular}

\section{Copyrights}

Copyright for this article is retained by the author, with first publication rights granted to the journal.

This is an open-access article distributed under the terms and conditions of the Creative Commons Attribution license (http://creativecommons.org/licenses/by/4.0/). 